\title{
Effect of fluticasone propionate on neutrophil chemotaxis, superoxide generation, and extracellular proteolytic activity in vitro
}

\author{
C G Llewellyn-Jones, S L Hill, R A Stockley
}

\begin{abstract}
Background - Corticosteroids are widely used in the treatment of many inflammatory conditions but the exact mode of action on neutrophil function is uncertain. Fluticasone propionate is a new topically active synthetic steroid which can be measured in body fluids and which undergoes first pass metabolism.

Methods - The effects of fluticasone propionate on the function of neutrophils isolated from normal, healthy control subjects and on the chemotactic activity of sputum sol phase were assessed.

Results - Preincubation of neutrophils with fluticasone propionate reduced the chemotactic response to $10^{-8} \mathrm{~mol} / 1 \mathrm{~F}$ Met-Leu-Phe (FMLP) and to a 1:5 dilution of sputum sol phase in a dose dependent manner. Furthermore, when fluticasone propionate was added to sputum from eight patients with stable chronic obstructive bronchitis the chemotactic activity of a 1:5 dilution of the sol phase fell from a mean (SE) value of $22 \cdot 2(1 \cdot 21)$ cells/field to $19.6(0.89), 17 \cdot 1(0 \cdot 74)$, and $11.9(0.6)$ cells field at $1 \mu \mathrm{mol} / 1,10 \mu \mathrm{mol} / 1$, and $100 \mu \mathrm{mol} / 1$, respectively. In further experiments fluticasone propionate preincubated with neutrophils inhibited fibronectin degradation by resting cells and by cells stimulated by FMLP (15.2\% inhibition of resting cells, $5 \cdot 1 \%$ inhibition of stimulated cells with $1 \mu \mathrm{mol} / 1$ fluticasone propionate, $24 \%$ and $18 \cdot 7 \%$ inhibition respectively at $100 \mu \mathrm{mol} / 1$ fluticasone propionate. Fluticasone propionate had no effect on generation of superoxide anion by resting or stimulated cells.

Conclusions - These results indicate that fluticasone propionate has a direct suppressive effect on several aspects of neutrophil function and may suggest a role for this agent in the modulation of neutrophil mediated damage to connective tissue.
\end{abstract}

(Thorax 1994;49:207-212)

Neutrophils have an important role in protecting the host against invasion by microorganisms. Neutrophil activation, recruitment to tissues, phagocytosis, release of proteinases, and generation of oxygen metabolites results in killing and elimination of the pathogen or antigen. Although this process is usually self limiting it may, in some circumstances, become continuous or excessive, thus contributing to inflammation and tissue damage. For this reason neutrophils are thought to be involved in the pathogenesis of a wide range of inflammatory diseases including chronic destructive lung disease. ${ }^{12}$

Neutrophils isolated from the peripheral blood of patients with emphysema show an enhanced response to chemotactic signals, and are able to degrade more connective tissue than normal. ${ }^{3}$ The implication of these findings is that, for a given chemotactic signal, neutrophils from these patients would be recruited in larger numbers than normal and cause more tissue damage. The lungs of patients with bronchitis contain increased numbers of neutrophils, ${ }^{4}$ suggesting continued recruitment. This indicates the presence of a chemotactic signal and lung secretions have been shown to possess chemotactic activity. ${ }^{5}$ Since the recruitment of neutrophils to the lung probably plays a major part in the pathogenesis of bronchitis and emphysema, ${ }^{4}$ factors which modulate this process will be of major importance in controlling disease progression. ${ }^{6}$

Corticosteroids have an important role in the treatment of inflammatory conditions, although their precise mode of action is not fully understood. In vitro studies have shown that corticosteroids are able to inhibit neutrophil chemotaxis, ${ }^{7-9}$ extracellular degranulation ${ }^{10}$ and, in some studies, superoxide anion generation, ${ }^{11}$ although the latter effect has not been confirmed by other workers. ${ }^{12}$ In vivo studies with oral corticosteroids in animals and man have confirmed an inhibition of the neutrophil chemotactic response, but have shown no effect on superoxide anion release. ${ }^{1314}$ In a further preliminary study inhaled beclomethasone dipropionate had an inhibitory effect on peripheral neutrophil chemotactic response and degranulation, as well as reducing sputum chemotactic activity and albumin concentrations, suggesting a beneficial effect on lung inflammation. ${ }^{15}$

Fluticasone propionate is a new, inhaled, topically active synthetic glucocorticosteroid which undergoes first pass metabolism in the liver, is quantifiable in body fluids, and has greater anti-inflammatory activity than beclomethasone dipropionate in animal studies. As a preliminary study before clinical evaluation of this inhaled steroid we have investigated the effects of fluticasone propionate on normal neutrophils in vitro. The aims of the present study were therefore, firstly, to assess the effect of fluticasone propionate on neutrophil chemotaxis, secondly to assess the in vitro 
effect of fluticasone propionate on neutrophil degranulation as measured by the degradation of fibronectin, and thirdly to assess the effect of fluticasone propionate on superoxide anion generation by neutrophils.

\section{Methods}

PREPARATION OF SPUTUM SOL PHASE

Sputum samples were collected from eight patients with stable chronic obstructive bronchitis receiving only inhaled bronchodilator treatment. The samples were ultracentrifuged at $50000 \mathrm{~g}$ for 90 minutes at $4^{\circ} \mathrm{C}$, the supernatant collected, aliquoted and stored separately. In addition purulent sputum was collected from several patients with bronchiectasis, the sol phase was obtained, and the samples were pooled and stored in separate aliquots. All samples were stored at $-70^{\circ} \mathrm{C}$ until required.

\section{ISOLATION OF BLOOD NEUTROPHILS}

Neutrophils were isolated by the method of Jepsen and Skottun. ${ }^{16}$ Briefly, venous blood from normal healthy controls was collected between 9.00 and 10.00 hours into lithium heparin tubes. Each sample was diluted with an equal volume of $0.15 \mathrm{~mol} / 1$ sodium chloride and layered onto a Percoll gradient (Sigma Chemicals, Dorset, UK). The top layer consisted of $2 \mathrm{ml} 54 \%$ Percoll (density $1.075 \mathrm{~g} / \mathrm{ml}$ ) and the lower layer of $3 \mathrm{ml} 78 \%$ Percoll (density $1.096 \mathrm{~g} / \mathrm{ml}$ ). The tubes were centrifuged for 25 minutes at $200 \mathrm{~g}$ at room temperature. The neutrophils ( $>96 \%$ pure, $>98 \%$ viable as assessed by exclusion of trypan blue) were harvested from the interface of the $54 \%$ and $78 \%$ layers, washed twice in $0.15 \mathrm{~mol} / 1$ saline solution, counted, and resuspended at the required concentration in relevant assay medium; RPMI 1640 medium (Flow Laboratories, Rickmansworth, UK) for the fibronectin degradation assay, RPMI solution containing $2 \mathrm{mg} / \mathrm{ml}$ bovine serum albumin for the chemotaxis assay, or phosphate buffered saline $(0 \cdot 15 \mathrm{~mol} / 1, \mathrm{pH} 7 \cdot 2)$ containing $1 \mathrm{~mol} / 1 \mathrm{calcium}$ chloride and $1 \mathrm{~mol} / 1$ magnesium chloride for the superoxide assay. All reagents were confirmed to contain less than $20 \mathrm{ng} / 1$ endotoxin activity using the KabiVitrum Coat test (Flow Laboratories, Rickmansworth, UK).

\section{NEUTROPHIL CHEMOTAXIS}

The chemotaxis assay was based on the method described by Falk et al ${ }^{17}$ using the 48-well micro chemotaxis chamber. The lower wells contained $27 \mu$ l chemoattractant $\left(10^{-8} \mathrm{~mol} / 1 \mathrm{~F}-\right.$ Met-Leu-Phe (FMLP) or 1:5 dilution of the sputum sol phase in RPMI with $2 \mathrm{mg} / \mathrm{ml}$ bovine serum albumin) and the upper wells contained $50 \mu \mathrm{l}$ cells at $1.5 \times 10^{6}$ cells $/ \mathrm{ml}$. Fluticasone propionate at varying concentrations $(0.01 \mu \mathrm{mol} / 1$ to $100 \mu \mathrm{mol} / \mathrm{l})$ was either preincubated with neutrophils for 30 minutes at $37^{\circ} \mathrm{C}$ before performing the assay and then added with neutrophils to the upper wells, or placed in the lower wells of the chamber with the chemoattractant. The upper and lower wells were separated by a $2 \mu \mathrm{m}$ pore PVP-free polycarbonate filter (Costar Nucleopore, Costar UK, High Wycombe, UK). The chemotaxis chamber was incubated at $37^{\circ} \mathrm{C}$ for 20 minutes, the filter was then removed, and the upper surface wiped across a wiper blade (to remove any cells that had not migrated through the pores) followed by fixing and staining with Diff-quick (Baxter, UK). The cells adherent to the lower surface were counted at $\times 400$ magnification from five random fields for each of three replicate wells. A mean value was obtained for each well and the average value for the replicates was taken as the result for that sample.

\section{FIBRONECTIN DEGRADATION}

Degradation of fibronectin was assessed by the method of Campbell et $a l^{18}$ modified by Burnett et al. ${ }^{3}$ Purified human fibronectin was obtained from the Sigma Chemical Co. (Poole, Dorset, UK) and iodinated by the chloramine$\mathrm{T}$ method with radiolabelled sodium 125iodide (ICN Flow, High Wycombe, UK). The radiolabelled fibronectin was diluted with unlabelled fibronectin in $0.05 \mathrm{~mol} / 1$ carbonate/ bicarbonate buffer, $\mathrm{pH} 9 \cdot 6$, to give $2000 \mathrm{cpm} /$ $\mu \mathrm{g}$ fibronectin, and dispensed into the wells of microtitre plates at $30 \mu \mathrm{g} /$ well. The plates were allowed to dry at $37^{\circ} \mathrm{C}$ and then washed three times with phosphate buffered saline ( $\mathrm{pH} 7 \cdot 2)$. The isolated neutrophils suspended in RPMI medium $\left(3 \times 10^{5}\right.$ cells $/$ well $)$ were dispensed into the wells and the plates incubated at $37^{\circ} \mathrm{C}$ in a humidified atmosphere of $5 \%$ carbon dioxide $/ 95 \%$ air for three hours. After incubation the supernatant was collected from the wells and the proteolysed fibronectin was measured by counting with an LKB Multigamma II gamma counter. The iodine-125 counts in the supernatants of wells containing RPMI medium alone (blank) were deducted from those containing neutrophils. All experiments were performed in the absence (resting) and presence (stimulated cells) of $1 \mu \mathrm{mol} / 1$ FMLP and the result for each assay was determined from the mean value for three replicate wells. The experiments were performed in two ways: (1) cells were preincubated with fluticasone propionate at varying concentrations $(0.01 \mu \mathrm{mol} / 1$ to $100 \mu \mathrm{mol} / 1)$ for 30 minutes followed by gentle mixing, before being added together onto the fibronectin plate (nreincubation), or (2) the cells were allowed to adhere onto the fibronectin for 30 minutes followed by fluticasone propionate (adherent cells). The values obtained for the adherent cells were corrected for the 30 minutes before the addition of fluticasone propionate.

\section{SUPEROXIDE ASSAY}

Superoxide release from neutrophils in suspension was determined by measuring the superoxide dismutase inhibitable reduction of ferricytochrome C. ${ }^{19}$ Neutrophils were preincubated with fluticasone propionate at varying concentrations $(1 \mu \mathrm{mol} / 1$ to $100 \mu \mathrm{mol} / \mathrm{l})$ for 30 minutes at $37^{\circ} \mathrm{C}$ and then dispensed $\left(10^{6}\right.$ cells 


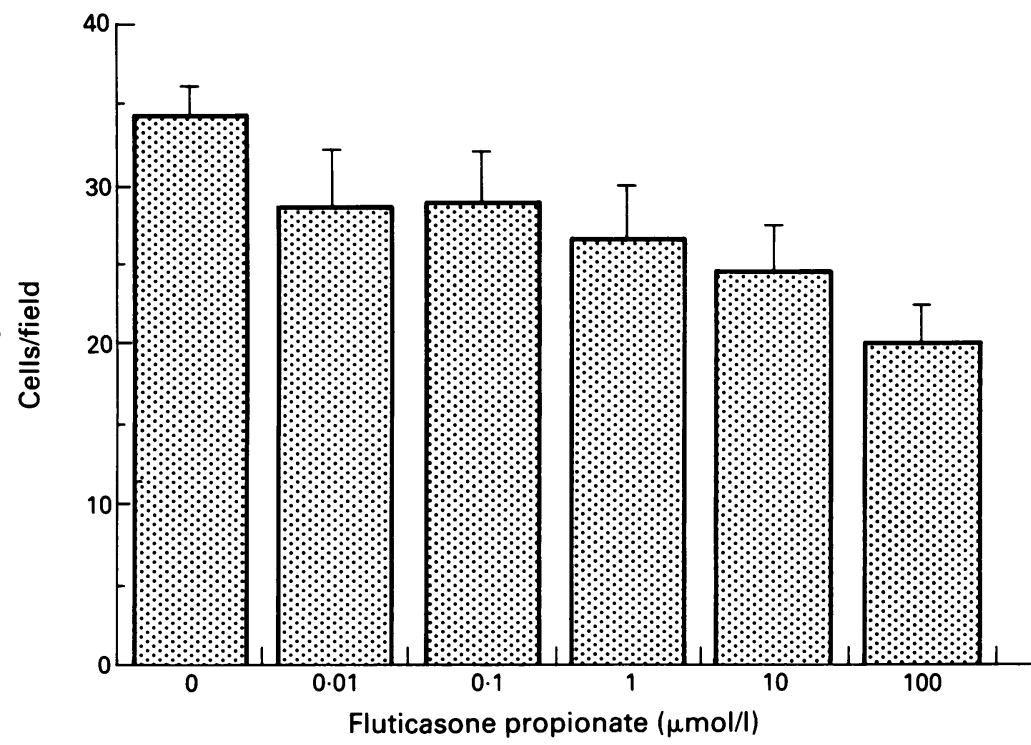

Figure 1 Inhibition of neutrophil chemotaxis to $10^{-8} \mathrm{~mol} / \mathrm{l}$ FMLP following preincubation with varying concentrations of fluticasone propionate. Each histogram is the mean (SE) of four experiments. A significant dose response is seen $(p<0.0001)$.

in $100 \mu \mathrm{l}$ phosphate buffered saline $0.15 \mathrm{~mol} / \mathrm{l}$, $\mathrm{pH} 7 \cdot 2$, containing $1 \mathrm{mmol} / \mathrm{l}$ calcium chloride and $1 \mathrm{mmol} / 1$ magnesium chloride) into the wells of a limbro plate ( 24 well, flat bottomed, Flow Laboratories). To reaction wells either $10 \mu \mathrm{l}(5 \mathrm{mg} / \mathrm{ml})$ superoxide dismutase (from bovine erythrocytes, Sigma) to mop up released superoxide, or $10 \mu \mathrm{l}$ reaction buffer, was added. Horse heart ferricytochrome C (Sigma) was added to all wells (to a volume of $100 \mu \mathrm{l}$ ) to make a final concentration of $10 \mathrm{mmol} / \mathrm{l}$. Fluti-

Table 1 Effect of fluticasone propionate (FP) on neutrophil chemotaxis to sputum from patients with bronchiectasis. Mean (SE) results $(n=4)$ are given for experiments when fluticasone propionate was preincubated with neutrophils $(p<0.0001)$ or added to the sputum $(p<0.0001)$

\begin{tabular}{lll}
\hline Concentration & $F P$ with neutrophils (cells/field) & FP in sputum (cells/field) \\
\hline Control & $29 \cdot 37(4 \cdot 1)$ & $31 \cdot 07(1 \cdot 7)$ \\
$0 \cdot 1 \mu \mathrm{mol} / 1$ & $26 \cdot 65(4 \cdot 1)$ & $26 \cdot 30(2 \cdot 0)$ \\
$1.0 \mu \mathrm{mol} / 1$ & $24 \cdot 75(3 \cdot 7)$ & $24 \cdot 12(1 \cdot 5)$ \\
$10 \mu \mathrm{mol} / 1$ & $22 \cdot 00(3 \cdot 4)$ & $23 \cdot 10(1 \cdot 1)$ \\
$100 \mu \mathrm{mol} / 1$ & $18.57(3.5)$ & $17.50(1.3)$ \\
\hline
\end{tabular}

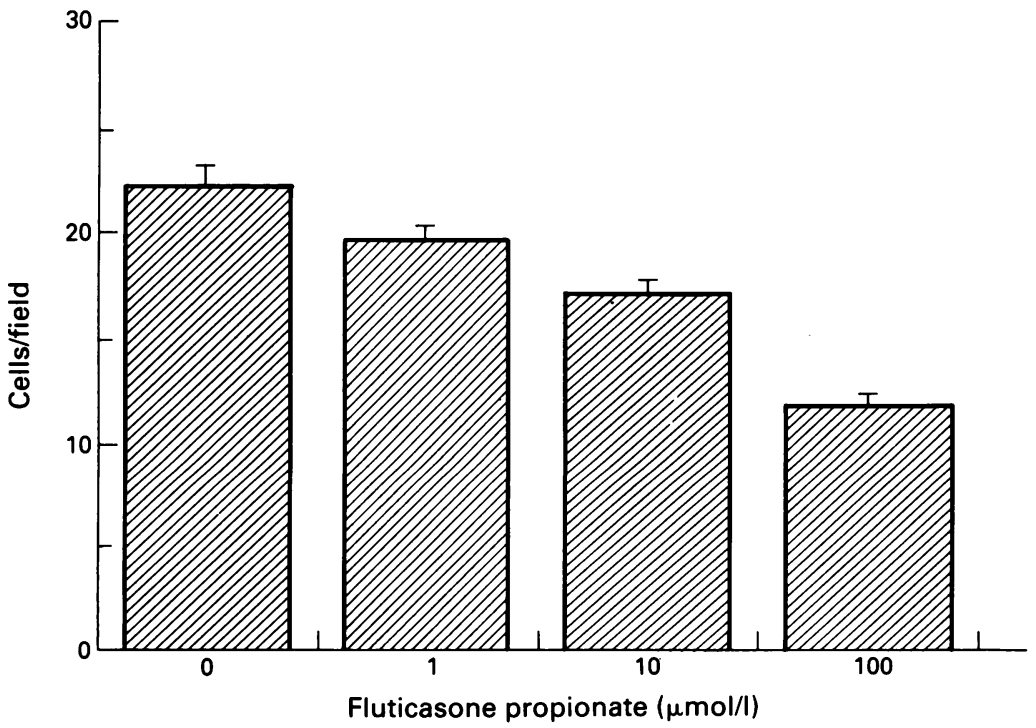

Figure 2 Mean (SE) dose related reduction in chemotactic activity of the sputum sol phase from eight patients with chronic obstructive bronchitis by fluticasone propionate added to the sputum $(p<0.001)$. casone propionate $(100 \mu \mathrm{l})$ at varying concentrations was added to test wells to achieve the same concentration incubated previously with neutrophils $(1 \mu \mathrm{mol} / 1$ to $100 \mu \mathrm{mol} / \mathrm{l})$. All experiments were performed in the presence (stimulated cells) and absence (resting cells) of $1 \mu \mathrm{mol} / 1$ FMLP. The total volume of each well was made up to $1 \mathrm{ml}$ with reaction buffer, with blank wells containing ferricytochrome $\mathrm{C}$ and reaction buffer alone. After incubation for one hour at $37^{\circ} \mathrm{C}$ in $5 \%$ carbon dioxide $/ 95 \%$ air, the supernatant from each well was recovered, centrifuged at $1000 \mathrm{~g}$ to remove any cells, and the absorbance of each sample was measured at $550 \mathrm{~nm}$ with a spectrophotometer. The amount of reduced cytochrome $C$ was calculated using an extinction coefficient of $21 \cdot 1 / \mathrm{nmol} .^{20}$ Neutrophil superoxide generation was calculated as the difference in absorbance between reaction wells with and without superoxide dismutase, and the results expressed as $\mathrm{nmol} / \mathrm{l}$ superoxide released per hour per $10^{6}$ cells.

\section{DATA ANALYSIS}

Statistical analyses of the dose effect of fluticasone propionate on neutrophil chemotaxis, degradation of fibronectin, and superoxide anion release were performed by analysis of variance.

\section{Results}

CELL VIABILITY

The viability of the neutrophils after incubation of the cells with up to $100 \mu \mathrm{mol} / \mathrm{l}$ fluticasone propionate remained $>98 \%$, as assessed by exclusion of trypan blue.

\section{CHEMOTAXIS}

When fluticasone propionate was preincubated with neutrophils inhibition of chemotaxis to FMLP occurred in a dose dependent manner (fig 1) from a mean (SE) control value of $34.2(2 \cdot 0)$ cells/field to $28.6(3.5), 28.8(3 \cdot 2)$, $26.6(3.2), 24.5(3.0)$ to $20.1(2.3)$ at 0.01 $\mu \mathrm{mol} / 1,0.1 \mu \mathrm{mol} / 1,1 \mu \mathrm{mol} / 1,10 \mu \mathrm{mol} / 1$, and $100 \mu \mathrm{mol} / 1$ fluticasone propionate respectively $(\mathrm{p}<0.0001)$. When sputum sol phase collected from patients with bronchiectatsis was used as the chemoattractant the results were similar whether fluticasone propionate was preincubated with neutrophils or whether it was added to the sputum (table 1). Again a dose related reduction in chemotactic response was seen $(\mathrm{p}<0.0001)$.

The mean (SE) chemotactic activity of a 1:5 dilution of the sputum sol phase collected from the eight patients with clinically stable chronic bronchitis was $22 \cdot 2(1 \cdot 2)$, range 16.9-27.2 cells/field. When fluticasone propionate was added to the sputum sol phase the chemotactic activity was again reduced in a dose dependent manner to $19.6(0.89)$, range $15.7-23.4$ at $1 \mu \mathrm{mol} / \mathrm{l} ; \quad 17 \cdot 1 \quad(0 \cdot 74)$, range $14.3-20 \cdot 2$ at $10 \mu \mathrm{mol} / \mathrm{l} ; 11.9(0.61)$, range $9.8-15.1$ at $100 \mu \mathrm{mol} / \mathrm{l}$, as summarised in fig 2 $(p<0.0001)$. In all experiments the back- 


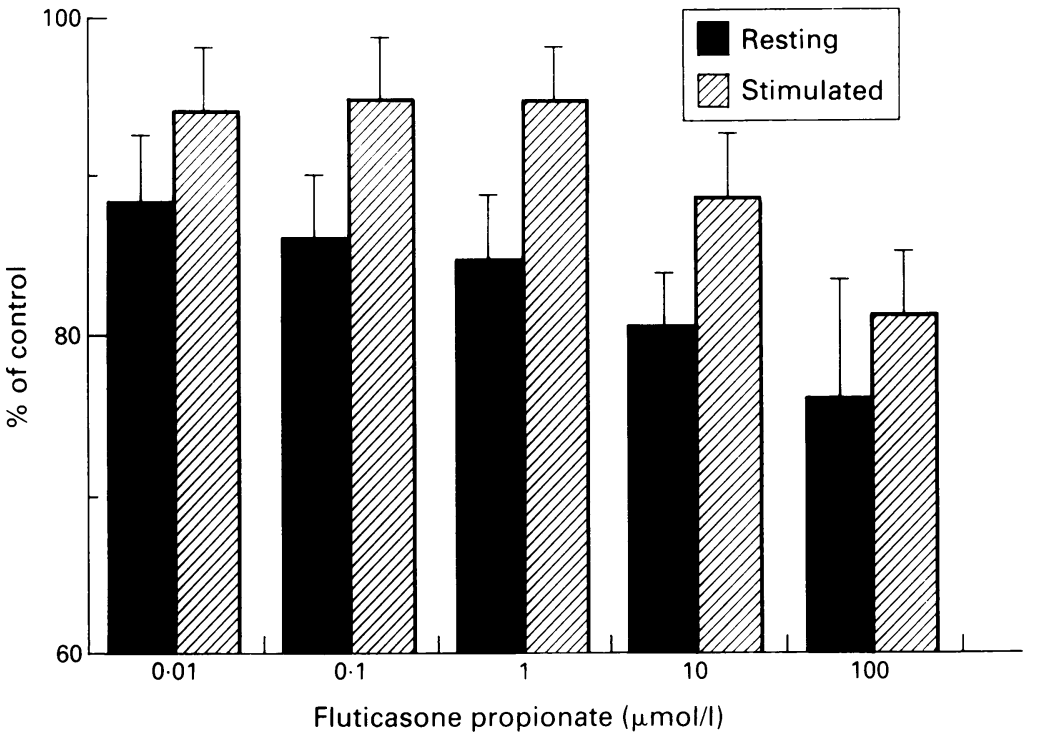

Figure 3 Inhibition of fibronectin degradation by resting and stimulated cells with varying concentrations of fluticasone propionate incubated with neutrophils before adherence to fibronectin. Each histogram represents the mean ( $S E$ ) of six experiments expressed as percentage change from control (no fluticasone propionate) ( $p<0.0005$ for resting cells and $p<0.0025$ for cells stimulated with FMLP).

ground chemotaxis/chemokinesis of neutrophils in the absence of chemoattractant was less than one cell/high power field.

\section{FIBRONECTIN DEGRADATION \\ Preincubation of fluticasone propionate with neutrophils}

Fluticasone propionate inhibited fibronectin degradation by resting and stimulated cells in a dose dependent manner when preincubated with neutrophils for 30 minutes before assessment. With resting neutrophils there was a reduction in degradation of fibronectin from a mean (SE) control value of $0.95(0.07) \mu \mathrm{g}$ fibronectin to $0.83(0.08) \mu \mathrm{g}, 0.82(0.08) \mu \mathrm{g}$, $0.81 \quad(0.08) \mu \mathrm{g}, \quad 0.79 \quad(0.08) \mu \mathrm{g}, \quad$ and 0.74 $(0 \cdot 1) \mu \mathrm{g}$, at $0.01 \mu \mathrm{mol} / 1,0.1 \mu \mathrm{mol} / 1,1 \mu \mathrm{mol} / 1$, $10 \mu \mathrm{mol} / 1$, and $100 \mu \mathrm{mol} / 1$ concentrations of fluticasone propionate, respectively $(n=6$, $\mathrm{p}<0.002)$. However, when the cells were stimulated with $1 \mu \mathrm{mol} / 1$ FMLP there was less inhibition of fibronectin degradation, with values falling from a control value of 1.7 $(0.27) \mu \mathrm{g}$ to $1.69(0.23) \mu \mathrm{g}, 1.65(0.29) \mu \mathrm{g}, 1.67$ $(0.28) \mu \mathrm{g}, 1.5(0.1) \mu \mathrm{g}$, and $1.36(0.2) \mu \mathrm{g}$ at the same concentrations of fluticasone propionate $(p<0.0005)$. The effect of fluticasone propionate on fibronectin degradation by resting and stimulated cells, expressed as percentage change from control values, is summarised in fig 3 .

Table 2 Effect of fluticasone propionate on fibronectin ( $F N$ ) degradation by resting and stimulated neutrophils added to cells tightly adherent to fibronectin $(p<0.05)$. Data are mean ( $S E$ ) of six experiments

\begin{tabular}{lll}
\hline Concentration & Resting neutrophils $(\mu g$ FN) & Stimulated neutrophils $(\mu g / F N)$ \\
\hline Control & $1.63(0.32)$ & $2.13(0.29)$ \\
$0.01 \mu \mathrm{mol} / 1$ & $1.40(0.26)$ & $1.99(0.32)$ \\
$0.1 \mu \mathrm{mol} / 1$ & $1.43(0.26)$ & $1.81(0.24)$ \\
$1.0 \mu \mathrm{mol} / 1$ & $1.43(0.24)$ & $1.78(0.20)$ \\
$10 \mu \mathrm{mol} / 1$ & $1.43(0.28)$ & $1.79(0.22)$ \\
$100 \mu \mathrm{mol} / 1$ & $1.43(0.28)$ & $1.75(0.20)$ \\
\hline
\end{tabular}

Treatment of adherent neutrophils with

fluticasone propionate

When fluticasone propionate was added to neutrophils that had been allowed to adhere to fibronectin, it was less effective at inhibiting fibronectin degradation than after preincubation with neutrophils as shown in table 2 . Values fell from a control of $1.63(0.32) \mu \mathrm{g}$ for resting cells to $1.43(0.24) \mu \mathrm{g}$ at both $1 \mu \mathrm{mol} / 1$ and $100 \mu \mathrm{mol} / 1(\mathrm{p}<0.05)$. When the adherent cells were stimulated with $1 \mu \mathrm{mol} / 1$ FMLP, fluticasone propionate reduced fibronectin degradation from $2.13(0.29) \mu \mathrm{g}$ to 1.78 $(0.2) \mu \mathrm{g}$ and $1.75(0.2) \mu \mathrm{g}$ at $1 \mu \mathrm{mol} / 1$ and $100 \mu \mathrm{mol} / 1$ respectively $(\mathrm{p}<0.05)$.

SUPEROXIDE ASSAY

When fluticasone propionate was preincubated with neutrophils for 30 minutes there was no change in resting or stimulated neutrophil superoxide anion generation: mean (SE) control value for resting cells of $2.5(0.50) \mathrm{nmol}$ $10^{6}$ cells/hour and $2.52(0.58)$ after incubation with fluticasone propionate at $1 \mu \mathrm{mol} / 1,2.55$ $(0 \cdot 74)$ at $10 \mu \mathrm{mol} / \mathrm{l}$ fluticasone propionate, and $2.53(0.69)$ at $100 \mu \mathrm{mol} / 1$ fluticasone propionate; when stimulated with $1 \mu \mathrm{mol} / 1$ FMLP the mean control was $3.78(0.63) \mathrm{nmol} /$ $10^{6} \mathrm{cells} /$ hour and $3.96(1.0), 3.48(0.58)$, and $3.67(0.63)$ with $1 \mu \mathrm{mol} / 1,10 \mu \mathrm{mol} / 1$, and $100 \mu \mathrm{mol} / 1$ fluticasone propionate respectively $(\mathrm{n}=3)$.

\section{Discussion}

The results show that fluticasone propionate has a direct suppressive effect on several neutrophil functions in vitro. It inhibited chemotaxis to both FMLP and sputum sol phase when preincubated with neutrophils, although high levels of fluticasone propionate were required with a $22.2 \%$ reduction in response at $1 \mu \mathrm{mol} / 1$ and $41 \cdot 2 \%$ at $100 \mu \mathrm{mol} / 1$. This is comparable with, although slightly greater than, values obtained in a previous study from our group using the same chemotaxis assay system to assess the effects of another glucocorticosteroid (dexamethasone) in vitro, and when administered systemically in vivo to normal healthy control subjects. ${ }^{13}$ The authors reported an $11 \%$ inhibition of neutrophil chemotaxis with $1 \mu \mathrm{mol} / 1$ dexamethasone, $29 \%$ at $100 \mu \mathrm{mol} / \mathrm{l}$, and $54 \%$ inhibition at $1 \mathrm{mmol} / 1$ dexamethasone in vitro. However, inhibition was achieved with much lower levels in vivo $(54 \%$ inhibition at $0 \cdot 126 \mu \mathrm{mol} / \mathrm{l})$, indicating greater efficacy when given as a treatment. This latter value is also similar to observations in patients with rheumatoid arthritis where there was a $60 \%$ reduction of neutrophil migration into the knee joint following the administration of intra-articular steroid. ${ }^{21}$

Sputum from patients with chronic destructive lung diseases has been shown to contain a number of unknown chemotactic factors, with greater chemotactic activity of purulent than mucoid sputum. ${ }^{5}$ We have confirmed this with purulent sputum collected from patients with bronchiectasis and from 
those with smoking related bronchitis and emphysema who produce mucoid sputum. We have assessed the chemotactic activity of each type of sputum using a 1:5 dilution of the sputum as this was found to be the optimum concentration. ${ }^{5}$ The chemotactic response of neutrophils to both types of sputum was reduced when fluticasone propionate was present in the sol phase with $22 \%, 26 \%$, and $44 \%$ inhibition at concentrations of 1,10 , and $100 \mu \mathrm{mol} / 1$ fluticasone propionate respectively for bronchiectatic sputum, and $12 \%, 23 \%$, and $46 \%$ inhibition respectively for bronchitic sputum. The presence of fluticasone propionate in lung secretions following inhalation treatment may therefore have a beneficial effect on lung inflammation by inhibiting neutrophil migration to the lung and thus reducing further tissue damage. However, as fluticasone propionate and neutrophils were added together into the upper wells of the chemotaxis chamber in the earlier experiment, it is difficult to separate the effects of the drug on the cells and on the sputum as some fluticasone propionate may have diffused through the pores into the lower wells during the assay.

Preincubation of neutrophils with fluticasone propionate for 30 minutes resulted in inhibition of fibronectin degradation by resting and stimulated cells in a dose dependent manner $(15 \%$ and $24 \%$ inhibition for resting cells at $1 \mu \mathrm{mol} / 1$ and $100 \mu \mathrm{mol} / 1$ respectively). When compared with previous work from our group using the same fibronectin degradation assay system to assess the effect of dexamethasone on neutrophil proteolysis, ${ }^{10}$ fluticasone propionate appears to be less effective. The authors reported an $11 \%$ inhibition of resting neutrophil fibronectin degradation by dexamethasone at $10^{-10} \mathrm{~mol} / 1,19 \%$ at $10^{-8} \mathrm{~mol} / \mathrm{l}$, $27 \%$ at $10^{-6} \mathrm{~mol} / 1$, and $42 \%$ at $10^{-4} \mathrm{~mol} / 1 .{ }^{10} \mathrm{In}$ our assay, however, fluticasone propionate was even less effective when the cells were stimulated with $1 \mu \mathrm{mol} / 1$ FMLP with only a $5 \cdot 1 \%$ inhibition at $1 \mu \mathrm{mol} / 1$ fluticasone propionate and $18.7 \%$ inhibition when the concentration was increased to $100 \mu \mathrm{mol} / 1$.

Allowing the cells to adhere to the fibronectin before the addition of fluticasone propionate resulted in only $12 \%$ inhibition with resting cells $(1 \mu \mathrm{mol} / 1$ and $100 \mu \mathrm{mol} / 1)$, and $16 \%$ and $18 \%$ inhibition respectively when the cells were stimulated. This activation of neutrophils by adherence or by FMLP appears to have reduced the effect of fluticasone propionate on fibronectin degradation. This may be because the activation of the cells by either mechanism is able to overcome the suppressive effects of fluticasone propionate, or that the activation process uses a different cell pathway which is not inhibited by fluticasone propionate.

Fluticasone propionate had no effect on neutrophil superoxide anion generation by resting or stimulated cells even at high concentrations. Several other workers have assessed the effects of steroids on superoxide production with variable results. There are reports of suppression of superoxide generation by steroids in vitro, ${ }^{11}$ with others failing to confirm this observa- tion..$^{912}$ In addition there are contradictory reports about the effects of steroids in vivo. ${ }^{1322}$ The results presented here suggest that steroids are unable to influence superoxide generation by neutrophils.

However, corticosteroids have a suppressive effect on other neutrophil functions in vitro and in vivo, although the mechanisms are not clearly understood. It is thought that the in vivo effects of steroids are caused by the synthesis of a phospholipase $A_{2}\left(P_{2} A_{2}\right)$ inhibitory peptide which inhibits the release of arachadonic acid, thereby limiting arachadonic acid metabolism and hence suppressing cell functions. ${ }^{23}$ However, this mechanism could not explain the rapid effects of steroids in vitro as the effect would require the synthesis of the inhibitory peptide which would take longer than the time scale of our in vitro experiments. More recently it has been suggested that glucocorticoids may inhibit PLA $_{2}$ directly by inducing dephosphorylation of the active form of the enzyme and thus would not involve the synthesis of a $\mathrm{PLA}_{2}$ inhibitory peptide. ${ }^{24}$ The latter mechanism would induce a more rapid response and may account for the suppression of neutrophil functions by glucocorticoids in vitro as shown here for fluticasone propionate. However, previous studies with indomethacin, which is known to inhibit $\mathrm{PLA}_{2},{ }^{25}$ have not shown any effect of this agent on the chemotactic response of mature neutrophils in vitro despite significant inhibition of neutrophil chemotaxis when given in vivo, ${ }^{26}$ suggesting that inhibition of $\mathrm{PLA}_{2}$ is not an important factor in the regulation of neutrophil function in vitro.

The results presented show that fluticasone propionate suppresses neutrophil function in vitro and that it also has an effect on the chemotactic activity of lung secretions. Fluticasone propionate has been formulated for inhalation in the treatment of steroid responsive obstructive lung diseases, and its ability to reduce the chemotactic response to sputum may be an important therapeutic factor in the treatment of chronic destructive lung diseases through inhibition of neutrophil recruitment and hence further tissue damage. In vivo studies using inhaled beclomethasone dipropionate in chronic bronchitis have shown a reduction in parameters of lung inflammation and an improvement in spirometric indices over a six week treatment period. ${ }^{27}$ In a preliminary study of beclomethasone dipropionate in similar patients the authors found a reduction of the chemotactic activity of sputum, inhibition of neutrophil chemotaxis to FMLP and degranulation, as well as a reduction in markers of lung inflammation. ${ }^{15}$ These findings support the concept of an overall benefit of such treatment in chronic lung disease. However, as beclomethasone dipropionate is absorbed into the blood stream it is difficult to distinguish its effects on circulating neutrophils and on lung inflammation. If the observations were due to a direct influence of the drug in the sputum with a beneficial effect on lung inflammation, this would reduce the release of chemotactic signals and hence neutrophil recruitment and 
activation. However, the observations may be due to a direct effect of the circulating drug on peripheral neutrophils with inhibition of neutrophil function and a secondary effect on sputum. Clinical studies with fluticasone propionate may provide a means of separating the effects of inhaled steroids on secretions from those on circulating cells because it undergoes first pass metabolism, and thus any effect of this inhaled drug in vivo will reflect only changes occurring in the lung. Furthermore, as fluticasone propionate is measurable in body fluids the results presented here can be compared directly with results obtained with this drug in future in vivo studies. Our results suggest that inhaled treatment with fluticasone propionate may reduce the chemotactic activity of lung secretions, reduce neutrophil recruitment to the lung and cell activation in lung tissues, while maintaining superoxide anion generation.

We acknowledge the financial support provided by Glaxo Group Research. We thank I Mitchell for preparing the sputum sol phase samples and Dr D Burnett for his comments on the manuscript.

1 Stockley RA. Proteolytic enzymes, their inhibitors and lung diseases. Clin Sci 1983;64:119-26.

2 Janoff A. Elastases and emphysema. Current assessment of the protease-antiprotease hypothesis. Am Rev Respir Dis 1985;132:417-33.

3 Burnett D, Chamba A, Hill SL, Stockley RA. Neutrophils from subjects with chronic obstructive lung disease show enhanced chemotaxis and extracellular proteolysis. Lancet 1987;ii:1043-6.

4 Morrison HM, Kramps JA, Burnett D, Stockley RA. Lung lavage fluid from patients with $\alpha_{1}$-proteinase inhibitor lavage fluid from patients with $\alpha_{1}$-proteinase inhibitor deficiency or chronic obstructive bronchitis: anti-elast

5 Stockley RA, Shaw J, Hill SL, Burnett D. Neutrophil chemotaxis in bronchiectasis: a study of peripheral cells chemotaxis in bronchiectasis: a study of peri

6 Stockley RA, Shaw J, Afford SC, Morrison HM, Burnett D. Effect of alpha-1 protease inhibitor on neutrophil chemotaxis. Am Y Respir Cell Mol Biol 1990;2:163-70.

7 Ward PA. The chemosuppression of chemotaxis. F Exp Med 1966;124:209-25.

8 Rivkin I, Foschi GV, Rosen CH. Inhibition of in vitro neutrophil chemotaxis and spontaneous motility by antiinflammatory agents. Proc Soc Exp Biol Med 1976;153:236-40

9 Freischlag JA, Colburn MD, Quinones-Baldrich WJ,
Moore WS. Alteration of neutrophil function by heparin, dexamethasone, and enalapril. F Surg Res 1992;52:523-9. 10 Burnett D, Chamba A, Hill SL, Stockley RA. Effects of plasma, tumour necrosis factor, endotoxin and dexameth asone on extracellular proteolysis by neutrophils from healthy subjects and patients with emphysema. Clin Sci 1989;77:35-41.

11 Fuenfer MM, Carr EA, Polk HC. The effect of hydrocortisone on superoxide production by leukocytes. $\mathcal{F}$ Surg Res 1979;27:29-35.

12 Mowat AG, Baum J. Chemotaxis of polymorphonuclear leukocytes from patients with rheumatoid arthritis. $7 \mathrm{Clin}$ Invest 1971;50:2541-9.

13 Lomas DA, Chamba A, Ip M, Stockley RA. The effect of dexamethasone on human neutrophil function in vitro and in vivo. Agents Actions 1991;33:279-85.

14 Fleming SD, Edelman LS, Chapes SK. Effects of corticosterone and microgravity on inflammatory cell production of superoxide 7 Leukoc Biol 1991:50:69-76.

15 Weir D, Jones S, Chamba A, Sherwood-Burge P, Stockley RA. The effect of inhaled beclomethasone dipropionate on peripheral neutrophil function in patients with chronic airflow obstruction. Thorax 1990;45:323P.

16 Jepsen LV, Skottun T. A rapid one-step method for the isolation of human granulocytes from whole blood. Scand f Clin Lab Invest 1982;42:235-8.

17 Falk W, Goodwin RH, Leonard EJ. A 48-well microchemotaxis assembly for rapid and accurate measurement of leucocyte migration. F Immunol Methods 1980;33:239 47.

18 Campbell EJ, Senior RM, McDonald JA, Cox DL. Proteolysis by neutrophils. Relative importance of cell-substrate contact and oxidative inactivation of proteinase inhibitors in vitro. 7 Clin Invest 1982;70:845-52.

19 Babior BM, Kipner RS, Curnette JT. Biological defense mechanisms: the production by leucocytes of superoxide, a potential bactericidal agent. $\mathcal{F}$ Clin Invest 1973;52:741

20 Van Gelder BF, Slater EC. The extinction coefficient of cytochrome C. Biochim Biophys Acta 1962;58:593-6.

21 Jones AK, al-Janabi MA, Solanki K, Sobnack R, Greenwood A, Doyle DV, et al. In vivo leukocyte migration in arthritis. Arthritis Rheum 1991;34:270-5.

22 Fukushima K, Ando M, Ito K, Suga M, Araki S. Stimulus and cumulative dose-dependent inhibition of $\mathrm{O}_{2}^{-}$production by polymorphonuclear leukocytes of patients receiving corticosteroids. 于 Clin Lab Immunol 1990;33:117-23.

23 Webb DSA, Roth JA. Relationship of glucocorticoid suppression of arachadonic acid metabolism to alteration of neutrophil function. $\mathcal{F}$ Leukoc Biol 1987;41:156-64.

24 Bailey JM. New mechanisms for effects of anti-inflammatory glucocorticoids. Biofactors 1991;3:97-102.

25 Shakir KMM, O'Brien JT, Gartner SL. Enhanced phospholipase $A_{2}$ activity in rat plasma, liver and intestinal pholipase $\mathrm{A}_{2}$ activity in rat plasma, liver and intestinal mucosa following endotoxin treatment. A possible explanation for the protective effect of indom

26 Ip M, Lomas DA, Shaw J, Burnett D, Stockley RA. Effect of non-steroidal anti-inflammatory, Stockley RA. Efrect chemotaxis - an in vitro and in vivo study. $\mathrm{Br} f$ Rheumatol 1990;29:363-7.

27 Thompson AB, Mueller MB, Heires AJ, Bohling TL, Daughton D, Yancey SW, et al. Aerolized beclomethasone in chronic bronchitis. Improved pulmonary function and diminished airway inflammation. Am Rev Respir Dis 1992;146:389-95. 